\title{
Long-Term Experimental Hypodynamy Affects the Structure of Spongy Bone and Osteoclasts in Japanese Quail
}

\author{
M. ZIBRÍN ${ }^{1}$, K. BOĎA ${ }^{2}$, V. CIGÁNKOVÁ ${ }^{1}$, J. KOČIŠOVÁ ${ }^{1}$, T. KOMOROVÁ ${ }^{1}$, \\ E. TOMAJKOVÁ ${ }^{1}$, V. SABO ${ }^{3}$, J. PIVKO ${ }^{4}$ \\ ${ }^{1}$ University of Veterinary Medicine, Košice, Slovak Republic \\ ${ }^{2}$ Research Institute of Veterinary Medicine, Ivanka pri Dunaji, Slovak Republic \\ ${ }^{3}$ Institute of Animal Biochemistry and Genetics SAS, Ivanka pri Dunaji, Slovak Republic \\ ${ }^{4}$ Research Institute of Animal Production, Nitra, Slovak Republic
}

Received June 16, 2002

Accepted March 25, 2003

\begin{abstract}
Zibrín M., K. Bod’a, V. Cigánková, J. Kočišová, E. Tomajková, T. Komorová, V. Sabo, J. Pivko: Long-term Experimental Hypodynamy Affects the Structure of Spongy Bone and Osteoclasts in Japanese Quail. Acta Vet Brno 2003, 72: 143-149.

We studied the effect of experimental hypodynamy on the structure of the two long bones (femur and tibiotarsus) of adult Japanese quail (Coturnix coturnix japonica) with special regard to osteoclasts. The quails were 70-day-old at the beginning of the experiment, they were euthanized after 28, 56, and 84 days of hypodynamy. Small pieces of bones were fixed, decalcified in EDTA, and routinely processed further for light and transmission electron microscopy. Structural changes in spongy bone and in the osteoclasts were found in all the experimental animals, compact bone was not affected. It seems that osteoclasts respond biphasically. First, after 28 days of hypodynamy, the number of osteoclasts diminished; they became vacuolated and had ruffled borders poor in microvilli. After 56 days of hypodynamy the osteoclasts recovered and became more numerous than in control animals; these osteoclasts possessed fully developed ruffled borders with many microvilli. After 84 days of hypodynamy the osteoclasts covered nearly the whole surface of the bone spicules and showed structural signs indicating their full activity.
\end{abstract}

Japanese quail, experimental hypodynamy, osteoclasts, spongy bone, light microscopy, transmission electron microscopy

Bones undergo continuous remodelling. In one year about one fourth of trabecular bone is renewed (Huiskes et al. 2000). The remodelling of bones is impaired frequently by many different factors, one of them is microgravity during space flights (Parfitt 1981; Ilyin and Oganov 1989; Kaplansky et al. 1987, 1991). Some minerals, particularly calcium, are washed out of bones due to microgravity, and the bone mass is also reduced. The loss of calcium may reach $200 \mathrm{mg}$ per day. These changes culminate after two months; later they do not seem to progress (Parfitt 1981). Microgravity during short-term space flights had little or only a slight adverse effect on the structure and development of bones in Japanese quails (Kaw a shima et al. 1995) and rats (Vico et al. 1988). The Japanese quail chicks studied within the Slovak space research programme "Quail Sk 6" remained in space lab for only a short time and because of that no changes in their bone structure due to microgravity were detected (Zibrín et al. 2001). Experiments in space are very demanding and because of that several research teams have tried to simulate microgravity (Huiskes et al. 2000) and other conditions of space flights in laboratories on Earth (Juráni et al. 1983; Wronsky and Morey 1983; Durnova et al. 1986; Navidi et al. 1995; Černý et al. 1998; Lebedeva et al.1998). In the study presented here we investigated the effect of long-term experimental hypodynamy on the structure of long bones of adult Japanese quails with special regard to osteoclasts. 


\section{Materials and Methods}

We studied the structure of 2 long bones (femur and tibiotarsus) of 12 adult Japanese quails (Coturnix coturnix japonica) of both sexes (6/6) after their exposure to experimental hypodynamy as described by Ju ráni et al. (1983) and Černý et al. (1998). Japanese quail line resistant to hypodynamy (Juráni et al. 1996) was used in this experiment. At the beginning of the experiment the Japanese quails were 70 days old. The hypodynamy lasted 28 , 56, and 84 days. Quails were suspended in special shirts below the ceiling of the cage so their feet did not touch the floor. They could consume food and water ad libitum. The experiments were carried out in accordance with all conditions specified by the Act about the rearing of laboratory animals and experiments on animals (Bugarský et al. 1999a, b). Animals of the same age, hatched at the same time, and fed the same diet were used as controls.

\section{Light microscopy (LM)}

Small pieces of bones were fixed in $4 \%$ neutral buffered formaldehyde, decalcified in buffered EDTA at pH 7.2 and routinely processed further. Paraffin embedding was used. The LM examination was carried out on both the paraffin sections 5-7 $\mathrm{m}$ m thick stained with haematoxylin-eosin and $1 \mathrm{~m}$ m Durcupan sections stained with toluidine blue cut from the material processed for transmission electron microscopy (TEM).

Transmission electron microscopy (TEM)

Pieces of bones $2-3 \mathrm{~mm}^{3}$ in size were immediately fixed in $3 \%$ buffered glutaraldehyde in $0.1 \mathrm{M}$ cacodylate buffer at $\mathrm{pH} 7.2$ for 3 hours. The fixed specimens were decalcified in buffered EDTA at pH 7.2. The decalcified specimens were post-fixed in $1 \% \mathrm{OsO}_{4}$ in $0.1 \mathrm{M}$ cacodylate buffer at $\mathrm{pH} 7.2$, dehydrated in acetone and embedded into Durcupan ACM. The ultrathin sections for TEM and the $1 \mathrm{~m} \mathrm{~m}$ sections for LM were cut on the ultramicrotome Tesla BS 490 using glass knives. The ultrathin sections stained with uranyl acetate and lead citrate were photographed in the electron microscope Tesla BS 500 at $60 \mathrm{kV}$.

\section{Results}

The LM showed that long-term experimental hypodynamy of Japanese quails induced both structural and quantitative changes in the substantia spongiosa, while the substantia compacta of the bones showed no essential changes. There was no substantial difference of in structure of spongy bone of femur and tibiotarsus of quails exposed to hypodynamy. TEM corroborated these observations. The spongy bone of adult control Japanese quail consists of bone spicules with osteoclasts on their surface (Plate I, Figs 1 and 3); different bone marrow cells and blood sinusoids were between bone trabeculae. Contrary to quail chicks in which the bone marrow is rich in adipocytes (Zibrín et al. 2001), there were only a few fat cells if any in the bone marrow of adult control quail (Plate I, Figs 1 and 2) as well as in experimental quails exposed to long term hypodynamy. The spongy bone of experimental quail exposed to 28-days of hypodynamy showed a reduction in bone marrow volume and in the number of vacuolized osteoclasts located on trabecular bone (Plate II, Figs 4-7). Osteoclasts of quail exposed to hypodynamy for 28 days as compared to controls had poorly developed ruffled borders (Figs 6 and 7). The surface area of bone trabeculae covered with osteoclasts was smaller than in the controls or in quail exposed to hypodynamy for 56 or 84 days. After 28 days of hypodynamy, almost all osteoclasts contained strongly shrivelled heterochromatic nuclei of irregular shape (Figs 4-7). The nuclei of osteoclasts of control (Figs 1 and 3) and experimental quail exposed to longer hypodynamy for 56 days (Plate III, Fig. 8) and particularly 84 days (Plate IV, Figs 12-14) were euchromatic and round, or oval. The amount of microvilli which constitute the ruffled border was different depending on the duration of hypodynamy. After 28 days of hypodynamy, the osteoclasts had ruffled borders deficient in microvilli (Figs. 6 and 7). After 56 or 84 days of hypodynamy the number of microvilli constituting the ruffled borders increased considerably. Particularly after the longer hypodynamy of 84 days (Plate IV, Fig. 13) microvilli in osteoclasts were even more numerous than those of control animals. Apart from the structural changes in the bones of adult Japanese quails induced by experimental hypodynamy, quantitative changes in the number of osteoclasts were observed after all three intervals of hypodynamy. On day 28 of hypodynamy, the number of osteoclasts decreased in comparison with the controls but after the 56-day hypodynamy, they were more numerous than in the controls. After hypodynamy 
lasting for 84 days, the amount of osteoclasts diminished, but they were still more numerous than in controls. After 56 and 84 days of hypodynamy, the osteoblasts were scarce and osteoclasts with well developed ruffled border covered almost the entire surface of bone trabeculae. Moreover, there were free star-shaped cells on the surface of bone trabeculae observed occasionally under LM (Plate III, Fig. 10). We identified them in TEM as osteocytes released from bone (Plate III, Fig. 11).

Our results indicate that osteoclasts respond biphasically. First, after 28 days of hypodynamy the number of osteoclasts drops, they become vacuolated and their ruffled border is poor in microvilli. After 56 days of hypodynamy, the osteoclasts recover and are more numerous than in the control animals; these osteoclasts possess fully developed ruffled borders with many microvilli. After 84 days of hypodynamy, osteoclasts cover nearly the whole surface of the bone spicules and show ultrastructural signs indicating their full activity.

Our observations of bone marrow of control quail showed that the red and white blood cells in different stages of their development were in contact with bone trabeculae (Fig. 2). After hypodynamy, such a situation was very rare. The surface of bone trabeculae of experimental quail was covered with osteoclasts or at least a thin layer of osteoclast cytoplasm, seen under the electron microscope (Fig. 9), separating the bone marrow cells from bone trabeculae. Apoptotic osteoclasts, osteoblasts or osteocytes were not found in this study. However, occasionally we observed apoptosis of various cells of the bone marrow, particularly after 84 days of hypodynamy (Plate IV, Fig. 15).

\section{Discussion}

We described the effect of long-term experimental hypodynamy on the structure of 2 long bones of adult Japanese quails using LM and TEM. Femur and tibiotarsus were selected for study because these bones bear the highest gravitational load (Černý et al. 1998). The experimental hypodynamy excludes the gravitational load on the pelvic limbs, particularly on the bones with long axis parallel to the gravity force which simulates microgravity conditions. We expected that the tibiotarsus would be the bone most affected by hypodynamy. Our morphological study fully confirmed this assumption.

Hypodynamy has unfavourable effects on Japanese quail. Long-term hypodynamy decreased the body weight of quail by an average of $14 \%$ (S abo et al. 1998) and adversely affected their behaviour. It induced reversible reproductive disorders due to impaired spermatogenesis and decreased egg laying (Lebedeva et al. 1998). Pravda et al. (1996) found that haematological parameters of Japanese quail exposed to hypodynamy increased to the upper limit of the physiological range and then subsequently declined to levels below controls. Leukocytes showed a similar shift i.e. rise and fall within physiological limit after 30 days of hypodynamy. A line of Japanese quail selected for resistance to hypodynamy for 12 generations (Juráni et al. 1996) had production efficiencies only slightly lower than controls (Chrappa et al. 1998).

The structure of bones after hypodynamy has been studied by several authors. Černý et al. (1998), using light microscopy detected no changes in the structure of bones in Japanese quail subjected to 28 days of hypodynamy; they observed changes in bone ossification after 56 days. A reduction in bone volume, decreased density of bones and loss of minerals from bones resulting in osteoporosis occurred in growing quail exposed to hypodynamy (Guryeva et al. 1998). Microgravity during orbital flight caused delay of growth of cartilage and the rate of skeleton ossification in quail embryos (Dad a shev a and Guryeva 1993). The effect on bone remodelling and particularly the reduction of bone mass in microgravity or weightlessness in space has been ascribed largely to the loss of osteoblasts, and to a smaller extent only, to the increased activity of osteoclasts (Durnova et al 1986; Kaplansky et al. 1987). 
Avian osteoclasts are derived from monocytes (Hanaoka 1979) and their development (Ko and Bernard 1981; Osdoby et al. 1982) and functions (Bonucci 1981) are similar to mammals (Burges s et al. 1999; Shalhoub et al. 2000; Sun et al. 2000). One of the characteristics of osteoclasts is that they are multinucleated cells. However, osteoclasts also include some cells that have only one nucleus (Domon and Wakita 1991; S un et al. 2000; Do mon et al. 2001). Not all multinucleated cells located on the surface of bones produce ruffled borders and possess tartrate resistant acid phosphatase, the enzyme typical of osteoclasts (Minkin 1982; Irie et al. 2000). Because of that some authors assumed than not all multinucleated cells found on the surface of bones are osteoclasts (Pazzaglia and Pringle 1989; Dersot et al. 1995). A number of authors observed that various physical factors or chemical substances cause the apoptosis of osteoclasts and osteoclasts-resembling odontoclasts (e.g. Ito et al. 1999; ZecchiOrlandini et al. 1999; Watanabe et al. 2000). The long-term hypodynamy in our quails caused rare apoptosis of bone marrow cells, however, we never found apoptotic osteoclasts. Similarly, B oabaid et al. (2001) using the TUNEL method were unable to find apoptotic osteoclasts in the alveolar bone of young rats; they only proved apoptotic osteoblasts and osteocytes. In the process of the resorption of bone trabeculae some osteocytes are released from bone lacunae to the surface of bone trabeculae which we also found in our study. However, like Suzuki et al. (2000) we did not observe apoptosis of these free osteocytes or their phagocytosis.

Remodelling of bones and the role of osteoclasts is important from a theoretical as well as practical point of view. A thorough knowledge of their functions is useful also for clinical practice in both human and veterinary medicine, e.g. in relation to osteoporosis of humans, particularly women in menopause ( $\mathrm{Li}$ et al. 1999; Teitelbaum 2000), in reconstructive craniofacial surgery (Jenča 1987; Der sot et al. 1995), bone transplantation (Ro soch a et al. 1999) and dental implants (Benghuzzi et al. 1999). Recently Jenča et al. (2001) successfully injected osteoblasts and osteoclasts into patients subjected to cranial bone surgery. The knowledge about the mechanism of activation or inactivation of osteoclasts may be of practical importance, too. Gruber et al. (2001) observed that high doses of estrogens inactivated rat osteoclasts, because they were unable to attach to bone and produce their ruffled borders. On the other hand, a deficiency of estrogens, e.g. due to ovariectomy, resulted in increased activity of osteoclasts which caused increased remodelling of trabecular bone and a decrease in the volume of trabecular bone (Abe et al. 1999). The stimulation of osteoclasts results in an increase of their surface which we observed in our study after 56 and particularly at 84 days of experimental hypodynamy. Our observations reveal that long-term experimental hypodynamy causes the activation of osteoclasts and the loss of spongy bone in adult Japanese quails.

During normal remodelling of bones the activity of osteoblasts and osteoclasts is balanced so the total volume of bone remains unchanged. Hu is kes et al. (2000) developed a computer model of metabolic processes in bones according to which the mechanical load and exercise increase the volume of bone while microgravity and inactivity reduce its volume which is in agreement with flight observations. The long-term space flights cause loss of bone, 2/3 of the total loss of the bone mass occurs in the spongy bone (Parfitt 1981). The changes in bones induced by microgravity in space or simulated experiments on Earth are caused mainly by the decreased activity of osteoblasts and increased activity of osteoclasts (Wronski and Morey 1982; Durnova et al. 1986). It is noteworthy that Vic o et al. (1987) found bone formation normal in some long-term immobilised volunteers but their bone resorption was increased which corresponds with immobilisation hypercalcemia in human patients (Evans et al. 1984). Our observations on osteoclasts support these findings. 


\section{Dlhodobá experimentálna hypodynamia má vplyv na štruktúru osteoklastov v hubovitých kostiach dospelých japonských prepelíc}

Študovali sme vplyv dlhodobej experimentálnej hypodynamie na štruktúru 2 dlhých kostí (femur a tibiotarsus) dospelých japonských prepelíc oboch pohlaví. Na začiatku pokusu prepelice mali 70 dní. Experimentálna hypodynamia trvala 28, 56 a 84 dní. Zistili sme, že dlhodobá hypodynamia spôsobuje zmeny v štruktúre hubovitej kosti a pokles jej objemu ako aj zmeny v počte a v štruktúre osteoklastov. Zdá sa, že reakcia osteoklastov je dvojfázová. Po poklese počtu osteoklastov na 28. deň hypodynamie, ked' osteoklasty majú štrukturálne znaky inhibície aktivity nastáva aktivácia osteoklastov. Po hypodynamii trvajúcej 56 dní počet osteoklastov stúpa a ich štruktúra ukazuje znaky plnej aktivity. Po hypodynamii trvajúcej 84 dní osteoklasty resp. ich cytoplazmatické výbežky pokrývajú značný, takmer celý povrch kostných trabekúl. Zriedkavo sme pozorovali apoptózu buniek kostnej drene, ale apoptózu osteoklastov ani osteoblastov sme nezistili.

\section{References}

ABE, T, SATO, K, MIYAKOSHI, N, KUDO, T, TAMURA, Y, TSUCHIDA, T, KASUKAWA, Y 1999: Trabecular remodelling processes in the ovariectomized rat: modified node-strut analysis. Bone 24: 591-596

BENGHUZZI, H, PUCKETT, A, TUCCI, M, ROBERTS, B 1999: Bioceramics surface modification by means of osteoclasts in culture. Biomed Sci Instrum 35: 321-326

BOABAID, F, CERRI, PS, KATCHBURIAN, E 2001: Apoptotic bone cells may be engulfed by osteoclats during alveolar bone resorption in young rats. Tissue Cell 33: 318-325

BONUCCI, E 1981: New knowledge on the origin, function and fate of osteoclasts. Review Clin Orthop 158: 252269

BUGARSKÝ, A, KORIM, P, TAKÁČOVÁ, D, PILIPČINEC, E 1999a: Akreditácia zariadení na chov laboratórnych zvierat a na vykonávanie pokusov na zvieratách. Slov vet čas 24: 270

BUGARSKY, A, KORIM, P, TAKÁČOVÁ, D, PILIPČINEC, E 1999b: Pokus na zvierati. Slov vet čas 24: 270 272

BURGESS,TL, QIAN, Y, KAUFMAN, S, RING, BD, VAN, G, CAPPARELLI, C, KELLEY, M, HSU, H, BOYLE, W,J, DUSTAN, CR, HU, S, LACEY, DL 1999: The ligand for osteoprotegerin (OPGL) directly activates mature osteoclasts. J Cell Biol 145: 527-538

ČERNÝ, H, BOĎA, K, SABO, V 1998: Microscopic study of selected skeletal structures during experimentally induced hypodynamy in Japanese quail (Coturnix coturnix japonica L, 1758). Folia vet 42 (Suppl):79-82

CHRAPPA, V, SABO, V, BOĎA, K 1998: Effect of long-term (84-days) hypodynamy on the efficiency of Japanese quails. Folia vet 42 (Suppl): 63-66

DADASHEVA, OA, GURYEVA, TS 1993: Bone and muscular tissue development in embryos and newly hatched quail incubated in weightlessness. Acta Vet Brno 62, Suppl 6: S51-59

DERSOT, JM, COLOMBIER, ML, LAFONT, J, BAROUKH, B, SEPTIER, D, SAFFAR, JL 1995: Multinucleated giant cells elicited around hydroxyapatite particles implanted in craniotomy defects are not osteoclasts. Anat Rec 242: 166-176

DOMON, T, WAKITA, M 1991: Electron microscopic and histochemical studies of the mononuclear osteoclast of the mouse. Am J Anat 192: 35-44

DOMON, T, SUZUKI, R, TAKATA, K, YAMAZAKI, Y, TAKAHASHI, S, YAMAMOTO, T, WAKITA, M 2001: The nature and function of mononuclear cells on the resorbed surfaces of bone in the reversal phase during remodelling. Ann Anat 183: 103-110

DURNOVA, GN, SAKHAROVA, ZF, KAPLANSKIJ, AS, IVANOV, VM, KHAIDAKOV, MS 1986: Quantitative study of the osteoblasts and osteoclasts in the bones of rats during the simulation of weightlessness (in Russian). Kosm Biol Aviakosm Med 20: 37-41

EVANS, RA, BRIDGEMAN, M, HILLS, E, DUNSTAN, CR 1984: Immobilisation hypercalcemia. Miner Electrolyte Metab 10: 244-248

GRUBER, HE, PUZANOV, LJ, BENNET, M, KUMAR, VV, GORDON, B 2001: 1terations in osteoclast morphology following long-term 17 beta estradiol administration in the mouse. BMC Cell Biol 2: 3

GURYEVA, TS, MEDNIKOVA, EI, DADASHEVA, OA, POVALKO, NB 1998: The musculoskeletal apparatus of Japanese quail during hypodynamy. Folia vet $\mathbf{4 2}$ (Suppl): 37-40

HANAOKA, H, 1979: The origin of the osteoclast. Review Clin Orthop 145: 252-263

HUISKES, R, RUIMERMAN, R, VAN LENTHE, GH, JANSSEN, JD 2000: Effect of mechanical forces on maintenance and adaptation of form in trabecular bone. Nature 405: 704-706

ILYIN, EA, OGANOV, VS 1989: Microgravity and musculoskeletal system of mammals. Adv Space Res 9: $11-19$ 
IRIE, K, ORIKASA, M, SAKAKURA, Y, TSURUGA, E, IWANAGA, T, YAJIMA, T 2000: Immunoreactivity to a monoclonal antibody (OS-3) is shared by osteoclasts and bicarbonate-secreting cells. Arch Histol Cytol 63: 255-259

ITO, M, AMIZUKA, N, NAKAJIMA, T, OZAWA, H 1999: Ultrastructural and cytochemical studies on cell death of osteoclasts induced by bisphosphonate treatment. Bone 25: 447452

JENČA, A 1987: L'osteotomie transversale d'expansion de l'angle mandibulaire. Encyclopédie Medicochirurgicale College de Medicine de Paris, 68-76

JENČA, A, ROSOCHA, J, ANDREJKO, S, HRBKOVÁ, H, JENČOVÁ, V 2001: Our results with bone allografts use in maxillofacial reconstructive surgery. Proceedings of the European Association of Tissue Banking. $10^{\text {th }}$ Anniversary Meeting. Eilat, Israel, p. 33

JURÁNI, M, VYBOH, P, LAMOŠOVÁ, D, BAROŠKOVÁ, M, SOMOGYIOVÁ, E, BOĎA, K, GAŽO, M 1983: The Physiologist, Suppl 26: 145-148

JURÁNI, M, VYBOH, P, LAMOŠOVÁ, D, KOŠŤÁL, L, BOĎA, K, SABO, V 1996: Selection of Japanese quail for resistance to hypodynamy and physiological consequences of selection. Acta Vet Brno 65: 57-64

KAPLANSKY, AS, DURNOVA, GN, SAKCHAROVA. ZF, ILJINA-KAKUEVA, EI 1987: Histomorphometric analysis of the bones of rats on board the Cosmos 1667 biosatellite. Kosm Biol Aviakosm Med 21: 25-31

KAPLANSKY, AS, DURNOVA, GN, BURKOVSKAYA, TE, VOROTNIKOVA, EV 1991: The effect of microgravity on bone fracture healing in rats flown on Cosmos-2044. Physiologist 34 Suppl 1: 196-199

KAWASHIMA, K, YAMAGUCHI, A, SHINKI, T, NOJI, S, YOKOSE, S, YAMAAI, T, ENDO, H, YOSHIKI, S, ABE, E, SUDA, T 1995: Microgravity generated by space flight has little effect on the growth and development of chick embryonic bone. Biol Sci Space 9: 82-94

KO J, S, BERNARD, GW 1981: Osteoclast formation in vitro from bone marrow mononuclear cells in osteoclastfree bone. Am. J. Anat 161: 415-425

LEBEDEVA, ZN, MEDNIKOVA, EI, GURYEVA, TS, DADASHEVA, OA, TRESVATSKAYA, NA, KALIUZHNAYA, MV 1998: Effect of hypodynamy on the organism of Japanese quail. Folia vet 42 (Suppl.): 53-56

LI, B, MARSHALL, D, ROE, M, ASPDEN, RM 1999: The electron microscope appearance of the subchondral bone plate in the human femoral head in osteoarthritis and osteoporosis. J Anat 195: 101-110

MINKIN, C 1982: Bone acid phosphatase: tartrate-resistant acid phosphatase as a marker of osteoclast function. Calcif Tissue Int 34: 285-290

NAVIDI, M, WOLINSKY, I, FUNG, P, ARNAUD SB 1995: Effect of excess dietary salt on calcium metabolism and bone mineral in spaceflight rat model. J Appl Physiol 78: 70-75

OSDOBY, P, MARTINI, MC, CAPLAN, AI 1982: Isolated osteoclasts and their presumed progenitor cells, the monocyte, in culture. J Exp Zool 224: 331-344

PARFITT, AM 1981: Bone effects of space flight: analysis by quantum concept of bone remodelling. Acta Astronaut 8: 1083-1090

PAZZAGLIA, UE, PRINGLE, JA 1989: Bone resorption in vitro: macrophages and giant cells from failed total hip replacement versus osteoclasts. Biomaterials 10: 286-288

PRAVDA, D, BOĎA, K, BAUMGARTNER, J, JELÍNEK, P, KUČÍNSKY, P, OKRUHLICA, M, PETROVSKÁ, E 1996: Haematological parameters of Japanese quail (Coturnix coturnix japonica) kept in cages under normal conditions and exposed to long-time experimental hypodynamy. Acta vet Brno 65: 93-97

ROSOCHA, J, JENČA, A, ANDREJKO, S, JENČOVÂ, V, VOLTÉROVÁ, K, HRBKOVÁ, H, 1999: Allograft in mandibule reconstruction. $12^{\text {th }}$ World Congress on Tissue Banking and $8^{\text {th }}$ International Conference of EATB „Allograft Against Disability“ p. 106, Warsaw, Poland

SABO, V, CHRAPPA, V, BODA, K, 1998: Performance parameters of two lines of Japanese quails improved under standard conditions and hypodynamy. Folia vet 42 (Suppl): 59-62

SHALHOUB, V, ELLIOT, G, CHIU, L, MANOUKIAN, R, KELLEY, M, HAWKINS, N, DAVY, E, SHIMAMOTO, G, BECK, J, KAUFMAN, SA, VAN, G, SCULLY, S, QI, M, GRISANTI, M, DUNSTAN, C, BOYLE, WJ, LACEY, DL 2000: Characterization of osteoclast precursors in human blood. Br J Haematol 111: 501-512

SUN, JS, CHANG, WS, HONG, RC, HUNG, TY, LIN, FH, LIU, HC 2000: Alveolar mononuclear cells can develop into multinucleated osteoclasts: an in vitro cell culture model. J Biomed Mater Res 52: 142-147

SUZUKI, R, DOMON, T, WAKITA, M 2000: Some osteocytes released from their lacunae are embedded again in the bone and not engulfed by osteoclasts during bone remodelling. Anat Embryol (Berl) 202: 119-128

TEITELBAUM, SL 2000: Bone resorption by osteoclasts. Science 289: 1504-1508

VICO, L, CHAPPARD, D, ALEXANDRE, C, PALLE, S, MINAIRE, P, RIFFAT, G, MORUKOV, B, RAKHMANOV, S 1987: Effects of a 120 day period of a bed-rest on bone mass and bone cell activities in man: attempts at countermeasure. Bone Miner 2: 383-394

VICO, L, CHAPPARD, D, PALLE, S, BAKULIN, AV, NOVIKOV, VE, ALEXANDRE, C 1988: Trabecular bone remodelling after seven days of weightlessness exposure (BIOCOSMOS 1667) Am J Physiol 255: R 243-247

WATANABE, J, AMIZUKA, N, NODA, T, OZAWA, H 2000: Cytochemical and ultrastructural examination of apoptotic odontoclasts induced by bisphosphonate administration. Cell Tissue Res 301: 375-387

WEZEMAN, FH, KUETTNER, KE, HORTON, JE 1979: Morphology of osteoclasts in resorbing fetal rat bone explants: effects of PTH and AIF in vitro. Anat Rec 194: 311-324 
WRONSKI, TJ, MOREY, ER, 1983: Recovery of the rat skeleton from the adverse effects of simulated weightlessness. Metab Bone Dis Relat Res 4: 347-352

ZECCHI-ORLANDINI, S, FORMIGLI, L, TANI, A, BENVENUTI, S, FIORELLI, G, PAPUCCI, L, CAPACCIOLI, S, ORLANDINI, GE, BRANDI, ML 1999: 17beta-estradiol induces apoptosis in the preosteoclastic FLG 29.1 cell line. Biochem Biophys Res Commun 255: 680-685

ZIBRÍN, M, CIGÁNKOVÁ, V, KOČIŠOVÁ, J, TOMAJKOVÁ, E, KOMOROVÁ, T, LENHARDT, L, SABO, V, BODA, K, DADASHEVA, OA, GURYEVA, TS 2001: The structure of some tissues and organs of Japanese quail hatched on the orbital space station „MIR“. Folia vet 45, Suppl: S17-S22

Explanation for figures: LM - light micrographs were taken from $1 \mathrm{~m}$ m Durcupan sections stained by touluidine blue, TEM - transmission electron microscopy. Both light and electron micrographs were taken from tibiotarsus. 
Plate I

Zibrín M. et al.: Long-Term... pp. 143-149

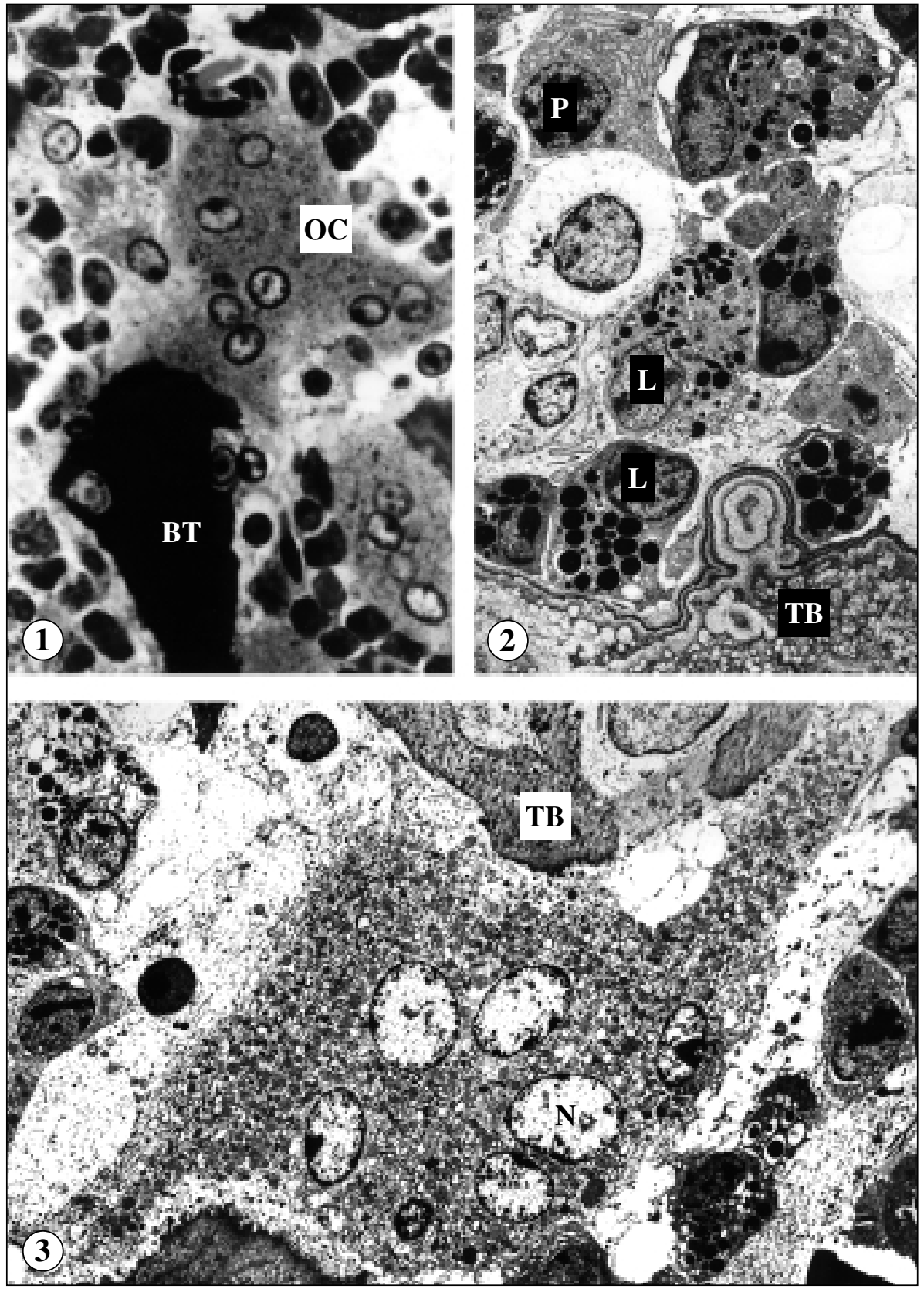

Fig. 1. Spongy bone and bone marrow of adult Japanese quail. The typical osteoclast (OC) contains several euchromatic nuclei and is in contact with bone trabecula (BT). LM, $\times 1200$

Fig. 2. The surface of trabecular bone (TB) and the bone marrow of the adult Japanese quail. Developing leukocytes $(\mathrm{L})$ and a plasma cell $(\mathrm{P})$ in bone marrow. TEM, $\times 4480$

Fig. 3. The osteoclast of adult Japanese quail with several round euchromatic nuclei $(\mathrm{N})$ making contact with trabecular bone (TB), the ruffled border is well developed. TEM, $\times 3200$ 


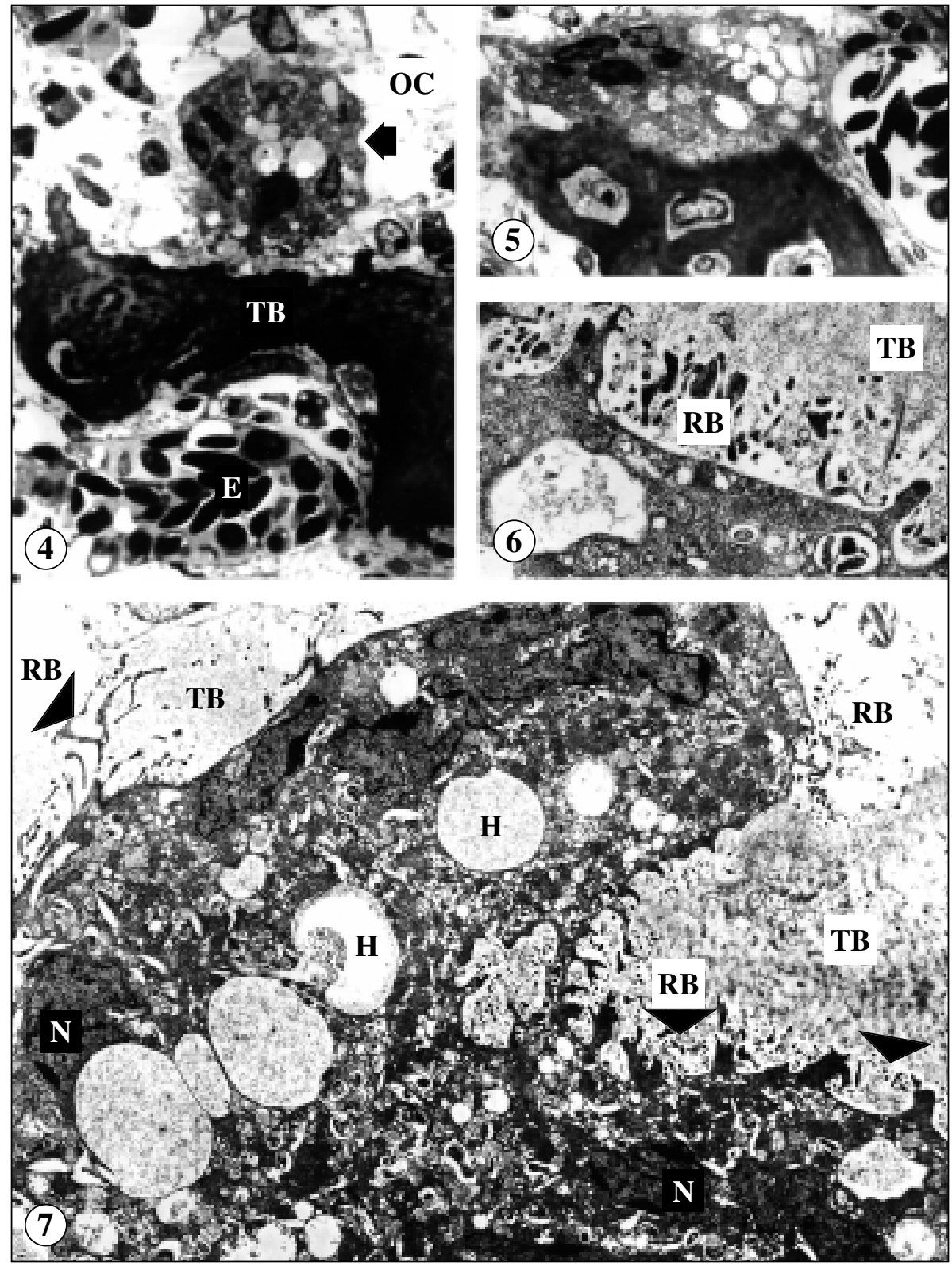

Fig. 4. The typical osteoclast (OC) of experimental quail after 28 days of hypodynamy containing vacuoles, its nuclei are shrunken and heterochromatic. The area of its contact with the surface of trabecular bone (TB) is very small. $\mathrm{E}$ - erythrocytes. $\mathrm{LM}, \times 1200$

Fig. 5. Another osteoclast from the same quail has more extensive area of contact with surface of the bone. $\mathrm{LM} \times 1200$.

Fig. 6. Part of the osteoclast after 28 days of hypodynamy. See heterophagic vacuole and the ruffled border (RB) with microvilli penetrating resorbed trabecular bone (TB). TEM, $\times 7360$

Fig. 7. The osteoclast after 28 days of hypodynamy has large heterophagic vacuoles $(\mathrm{H})$, the nuclei $(\mathrm{N})$ are heterochromatic and the ruffled border $(\mathrm{RB})$ is poor in microvilli. TB - trabecular bone. TEM, $\times 4160$ 

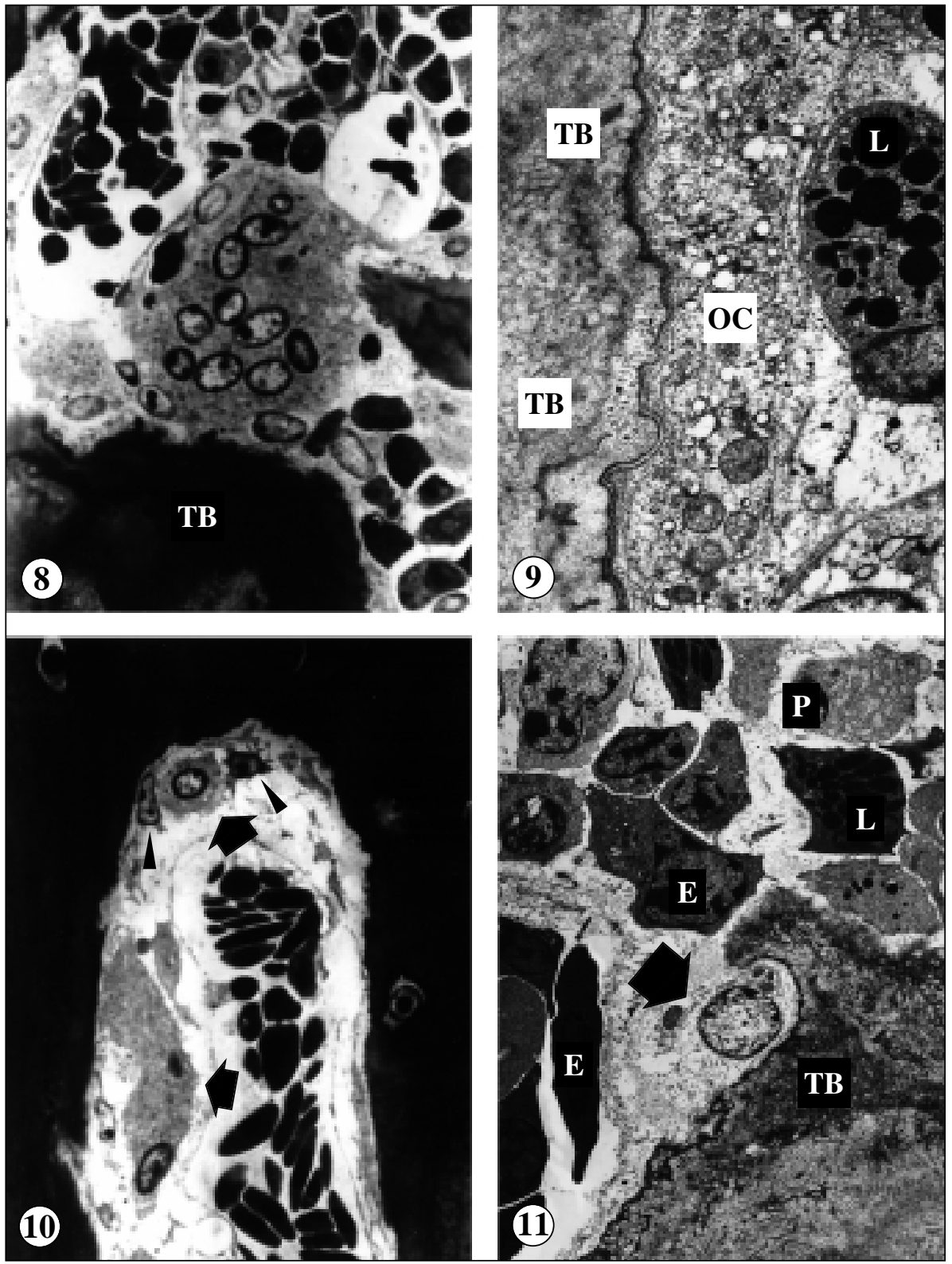

Fig. 8. The typical osteoclast on the surface of trabecular bone (TB) of Japanese quail after 56 days of hypodynamy looks like those in control animals. LM, $\times 1200$

Fig. 9. Trabecular bone (TB) of Japanese quail after 56 days of hypodynamy covered by the thin layer of cytoplasm of the osteclast (OC). Leukocyte (L) is not in touch with bone as in bone marrow of a control quail. TEM, $\times 7360$

Fig. 10. The blood sinusoid penetrating into the trabecular bone (black) after 56 days of hypodynamy. Note the mononuclear osteoclasts (arrows) and free osteocytes (thin arrowheads) released from the bone. LM, $\times 1200$ Fig. 11. Free osteocyte (arrow) on the surface of trabecular bone (TB) after 56 days of hypodynamy. Plasma cell $(\mathrm{P})$ and erythrocytes $(\mathrm{E})$ and leukocytes $(\mathrm{L})$ in different stages of development. TEM, $\times 3360$ 


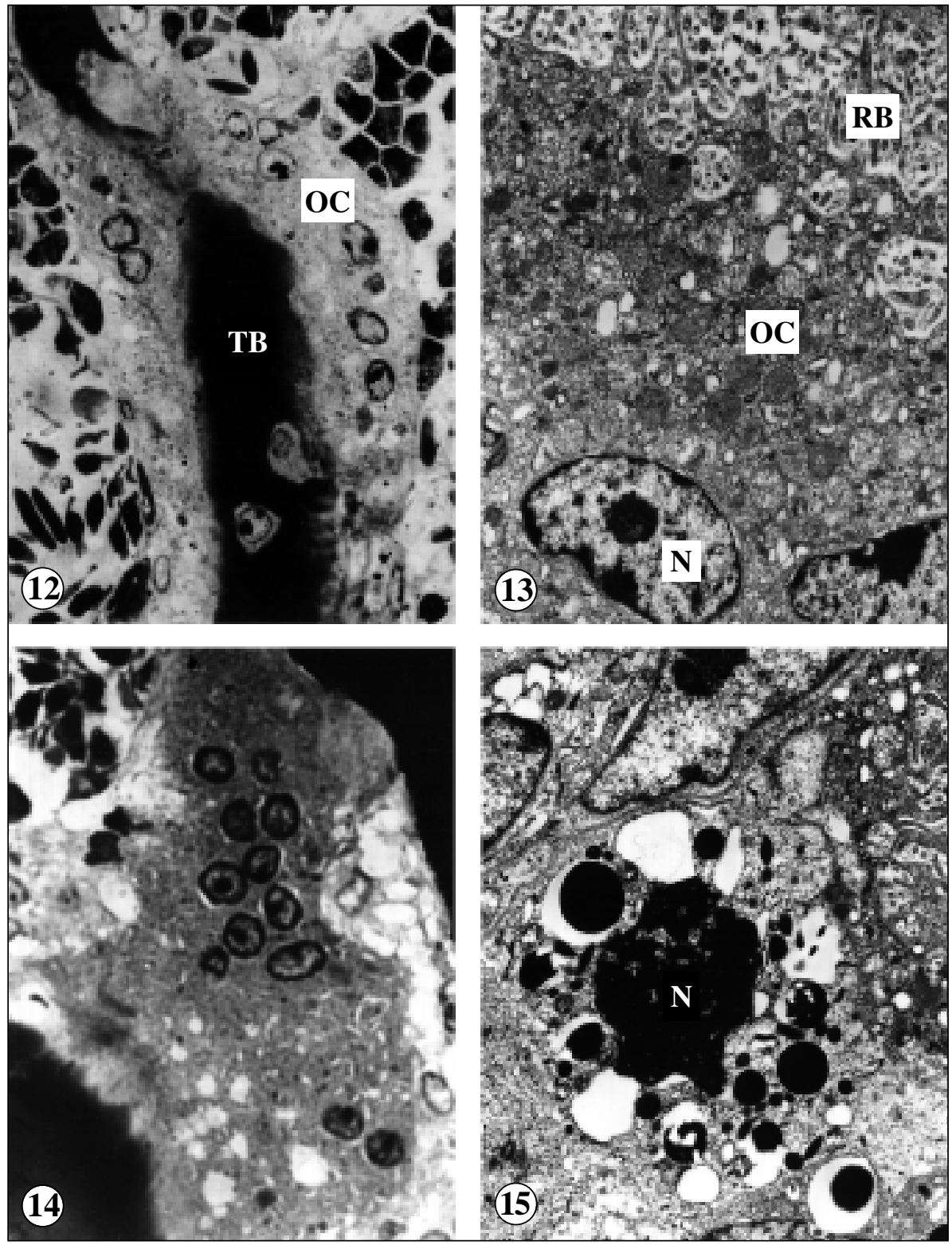

Fig. 12. Trabecular bone (TB) of Japanese quail after 84 days of hypodynamy. The osteoclasts (OC) cover most of the surface of the bone trabeculae. LM, $\times 1200$

Fig. 13. Part of the osteoclast (OC) after 84 days of hypodynamy. The osteoclastic cell nuclei (N) are euchromatic, the ruffled border (RB) is well developed. TEM, $\times 7680$

Fig. 14. Trabecular bone of Japanese quail after 84 days of hypodynamy with typical multinucleated osteoclast. LM, $\times 1200$

Fig. 15. Apoptosis of bone marrow cell after 84 days of hypodynamy. Dense apoptotic cell nucleus (N). TEM, $\times 7680$ 